\title{
THE BEHAVIOR OF INFILLED STEEL FRAMES UNDER REVERSE CYCLIC LOADING
}

\author{
M. Yasar Kaltakci ${ }^{1}$ and Ali Koken ${ }^{2, *}$ \\ ${ }^{1}$ Professor, Department of Civil Engineering, Engineering Faculty, Selcuk University, Konya, Turkey \\ ${ }^{2}$ Assistant Professor, Department of Civil Engineering, Engineering Faculty, Selcuk University, Konya, Turkey \\ *(Corresponding author: E-mail: : akoken@selcuk.edu.tr)
}

Received: 8 November 2012; Revised: 14 January 2013; Accepted: 13 March 2013

\begin{abstract}
The objective of this study was to make an experimental investigation on the behavior of nine steel frames with various infill characteristics under reverse cyclic loading. The test specimens, which were one-story steel frames, had the frame length/height ratios $(1 / h)$ of $1,1 / 2$, and 2 . The infill characteristics of the specimens were assigned as i) no infill, ii) brick wall infill, iii) brick wall+plaster infill. The specimens were tested under reverse cyclic loading representing the seismic loading in the horizontal direction, and the displacement values obtained during the tests were measured and recorded in a digital manner. At the end of the tests, the infilled frames were evaluated in terms of failure types, strength envelopes, energy consumption characteristics, and stiffness decreases by comparing the test results.
\end{abstract}

Keywords: Steel frames with infill walls, seismic behavior of infilled steel frames

\section{INTRODUCTION}

It is a known reality that infill walls considerably change the behavior of frames under horizontal loads and especially affect the strength, rigidity, and energy consumption properties. Studies on the structural behavior and response of masonry infilled frames trace back to as early as the 1950s [4]. The behavior of infilled frames under lateral loads has been investigated by a number of researchers. Findings and theories pertaining to infilled frames since the 1950s to the late 1980s were presented in a state of the art report prepared by Moghaddam et al. [12]. In general, researchers employed two different testing schemes in their investigations. The first was in-plane, diagonal, and compressive loading of a single frame unit, and the second in a plane racking test in which the frame is subjected to a top lateral load [4]. Holmes [5], Stafford [13, 14], Mainstone and Weeks [10], Dawe and Seah [1], Flangan et al. [3], Mander et al. [11], and Dukuze et al [2] have studied the behavior of masonry infilled steel frames under lateral loads [9].

In this study, an experimental investigation was executed to explore the effect of infill walls on steel frame systems in which infill walls are not generally taken into consideration in the structural analysis. Nine single story steel frame systems with various infill wall properties were tested under horizontal a reverse cycling load simulating a seismic load, and the results were examined and concluded [6], [7], [8].

\section{OBJECT AND SCOPE}

The objective of this study is to investigate the following: the effect of infill walls on strength, horizontal rigidity and energy consumption capacity of steel frames under a horizontal load, the failure types of infilled steel frame systems, and the effects of various infill wall properties and infill wall length/height $(1 / \mathrm{h})$ ratios on the seismic behavior of the steel frame system. With this purpose, throughout the study, nine steel frame systems on approximately a $1 / 3$ scale were tested under reverse cycling horizontal loading. The variables considered in deciding the test specimens 
were the length/height $(1 / \mathrm{h})$ ratio of the infill wall and properties of the infill wall. Considering these variables, the following test specimens were prepared and the experiments were performed.

1. Frame systems of infill wall length/height ratio $(1 / h)=1$, a-frame system with no infill - N110 $(1 / \mathrm{h}=1)$, b-Steel frame system with brick wall infill $-\mathrm{N} 111(\mathrm{l} / \mathrm{h}=1)$, $\mathbf{c}$ - frame system with brick wall + plaster infill $-\mathrm{N} 112(1 / \mathrm{h}=1)$

2. Frame systems of infill wall length/height ratio $(1 / \mathrm{h})=2$, a- frame system with no infill $-\mathrm{N} 110$ $(\mathrm{l} / \mathrm{h}=2)$, b-Steel frame system with brick wall infill $-\mathrm{N} 111(\mathrm{l} / \mathrm{h}=2), \mathbf{c}$ - frame system with brick wall + plaster infill $-\mathrm{N} 112(\mathrm{l} / \mathrm{h}=2)$

3. Frame systems of infill wall length/height ratio $(1 / \mathrm{h})=1 / 2$, a-frame system with no infill $\mathrm{N} 110(1 / \mathrm{h}=1 / 2), \mathbf{b}$-frame system with brick wall infill $-\mathrm{N} 111(\mathrm{l} / \mathrm{h}=1 / 2), \mathbf{c}$-frame system with brick wall + plaster infill $-\mathrm{N} 112(\mathrm{l} / \mathrm{h}=1 / 2)$

\section{PRESENTATION OF TEST MECHANISM AND TEST TECHNIQUE}

U-profiles, manufactured by bending cold steel plates for the preparation of steel frames, were used. Welding these U-profiles with arc welding, steel frames were formed with rigid nodal points and infill walls with various properties were placed there inside the steel frames. For brick wall infill, a horizontal hollow block brick of $190 \times 185 \times 85 \mathrm{~mm}$ was used. The brick wall+plaster infilled specimens had $17.5 \mathrm{~mm}$ plaster formed from lime with added cement mortar on both sides of the brick wall. For the masonry of the brick wall and plaster, the same cement mortar was used. The physical and geometric properties of the prepared test specimens are given in Table 1.

Table 1. Physical and Geometric Characteristics of Test Specimens

\begin{tabular}{cccccc}
\hline Specimens & Infill properties & $\begin{array}{c}\text { Frame } \\
\text { length } \\
(\mathrm{l})\end{array}$ & $\begin{array}{c}\text { Frame } \\
\text { height } \\
(\mathrm{h})\end{array}$ & $\begin{array}{c}\text { Infill } \\
\text { length } \\
\left(\mathrm{l}_{\mathrm{p}}\right)\end{array}$ & $\begin{array}{c}\text { Infill } \\
\text { height } \\
\left(\mathrm{h}_{\mathrm{p}}\right)\end{array}$ \\
\hline $\mathrm{N} 110(\mathrm{l} / \mathrm{h}=1)$ & No infill (empty) & 843.7 & 823.7 & 810 & 790 \\
\hline $\mathrm{N} 111(\mathrm{l} / \mathrm{h}=1)$ & Brick wall infill & 843.7 & 823.7 & 810 & 790 \\
\hline $\mathrm{N} 112(\mathrm{l} / \mathrm{h}=1)$ & Brick wall+ plaster infill & 843.7 & 823.7 & 810 & 790 \\
\hline $\mathrm{N} 110(\mathrm{l} / \mathrm{h}=2)$ & No infill (empty) & 1643.7 & 823.7 & 1610 & 790 \\
\hline $\mathrm{N} 111(\mathrm{l} / \mathrm{h}=2)$ & Brick wall infill & 1643.7 & 823.7 & 1610 & 790 \\
\hline $\mathrm{N} 112(\mathrm{l} / \mathrm{h}=2)$ & Brick wall+ plaster infill & 1643.7 & 823.7 & 1610 & 790 \\
\hline $\mathrm{N} 110(\mathrm{l} / \mathrm{h}=1 / 2)$ & No infill (empty) & 843.7 & 1603.7 & 810 & 1570 \\
\hline $\mathrm{N} 111(\mathrm{l} / \mathrm{h}=1 / 2)$ & Brick wall infill & 843.7 & 1603.7 & 810 & 1570 \\
\hline $\mathrm{N} 112(\mathrm{l} / \mathrm{h}=1 / 2)$ & Brick wall+ plaster infill & 843.7 & 1603.7 & 810 & 1570 \\
\hline
\end{tabular}

\subsection{Test Technique}

The experimental part of this study was performed in the structure laboratory of Selcuk University. The prepared nine steel frame specimens with various properties were tested under a horizontal reverse cycling load, which simulates seismic load by using a rigid loading frame system. During the experiment, the necessary load and displacement readings were made and recorded using a computer-aided data reading system. The experiment mechanism used in the tests is presented in Figure 1. 
The rigid loading frame was manufactured from various steel profiles and designed properly to apply the horizontal load. The system had a rigid base plate that enabled test specimens to be rigidly supported. The specimens could be rigidly supported to the rigid base plate using bolts. Thus, any rotation and translation of the specimen at the bottom were prevented. The horizontal load was applied to the steel frame specimen with the assistance of a hydraulic jack and a tension bar that was fixed on the loading plate supported on the vertical columns of the rigid loading frame. The hydraulic jack system could operate bi-directionally, meaning that it could apply both tension and compression force to the specimen. While the hydraulic jack system pushes the specimen fastened with the bolts in the compression stage, it pulls the specimen in the tension stage with the help of the steel tension bar of $\phi 40 \mathrm{~mm}$ and extending to the back end of the specimen at the top capital. In this way, it was possible to apply a horizontal reverse cycling load to the specimen. The steel bar also aided in preventing the specimen from tilting. In order to prevent the tilting of the specimens, steel profiles fixed to the horizontal branches of the rigid loading frame were used. While the branches perpendicular to the test frame that were welded to the profiles in the vertical position did not prevent the movement of the specimen through the loading direction with the shear loading mechanism, they only prevented the tilting of the specimen during load application by not taking on any load. A load cell together with the hydraulic jack was placed on the loading plate supported by the vertical branches of the rigid loading frame to perform the load readings. The loading frame was designed as rigid as possible to minimize horizontal and vertical motion, and the rotation of the loading mechanism formed from a pump and a load cell at values closer to zero so not affect the measurements during the test.

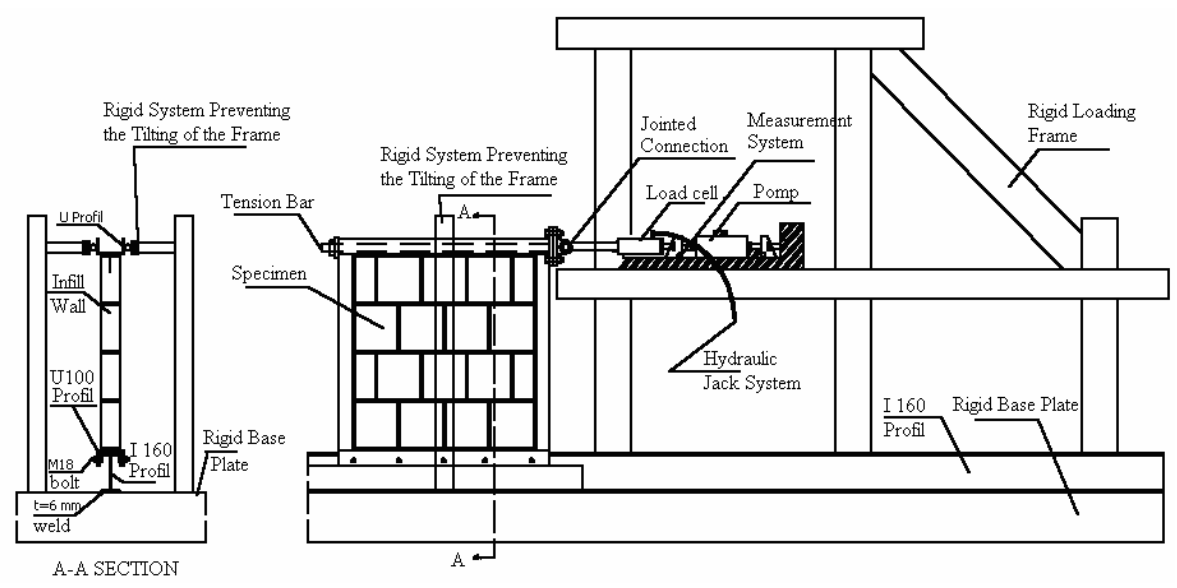

Figure. 1 The Loading System used in the Tests

\subsection{The Measurement Mechanism Used in the Tests}

A measurement system that was as similar as possible was used for every frame tested in the experiments. The measurement of the displacements occurred at the steel frame and the infill wall during the test that was performed using LVDTs of $0.01 \mathrm{~mm}$ accuracy. The required numbers of LVDTs are placed in the necessary locations to determine the horizontal displacements of the bottom and top ends of the steel frame system and rotations at the bottom and top capitals. Load measurements are made by using a load cell working in contact with the hydraulic jack. The measurement mechanism used in the tests is presented in Figure 2. 


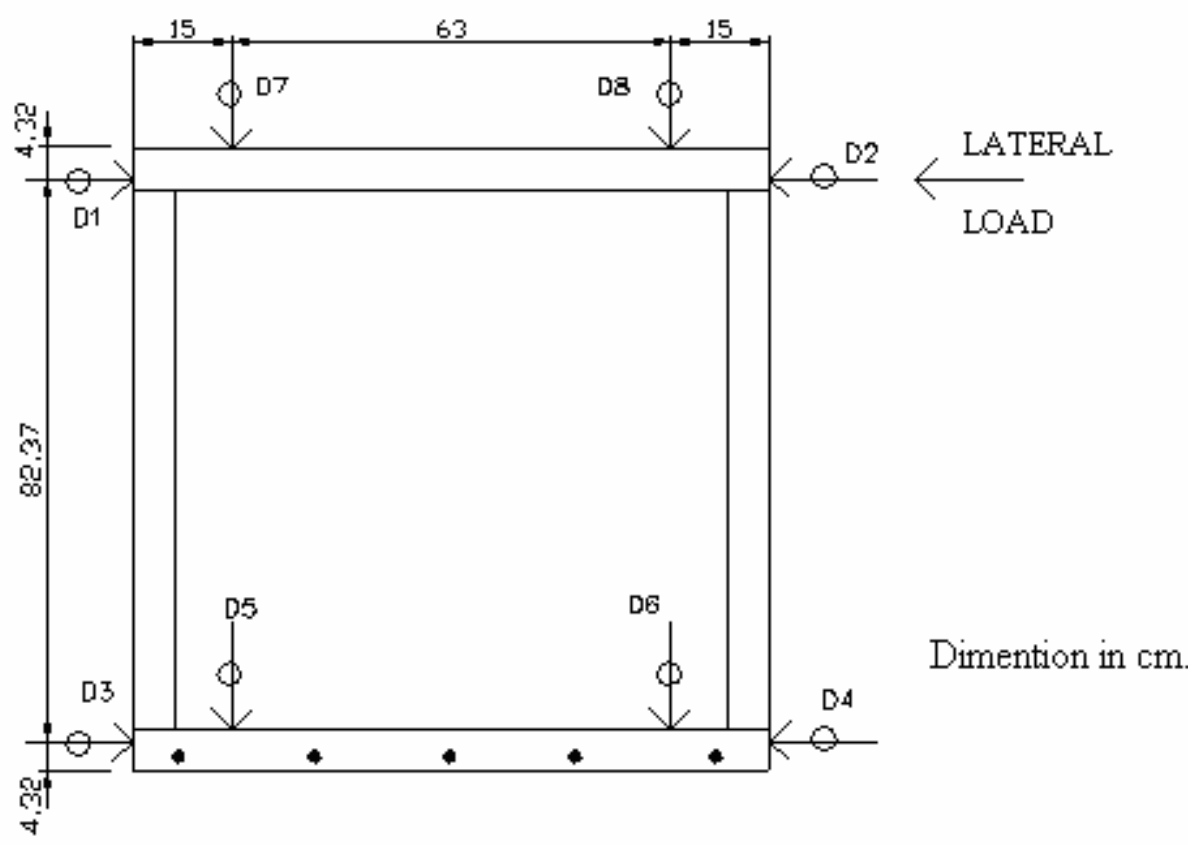

Figure 2. The Measurement Mechanism used for $1 / \mathrm{h}=1$ Tests

\subsection{Loading Program}

All the tests were carried out under displacement control. The loading control was performed by beginning from the stationary position and increasing $10 \mathrm{~mm}$ in each cycle as given in Figure 3 . The purpose of selecting such a loading program was to determine a systematic method in comparing the results between the specimens, because each of the frame system has different structural characteristics (empty, infilled with brick wall, infilled with brick wall + plaster). Therefore, each frame system would be evaluated according to horizontal displacement and $(\delta / h)$ ratio with the desired behavior characteristics and compared with other specimens.

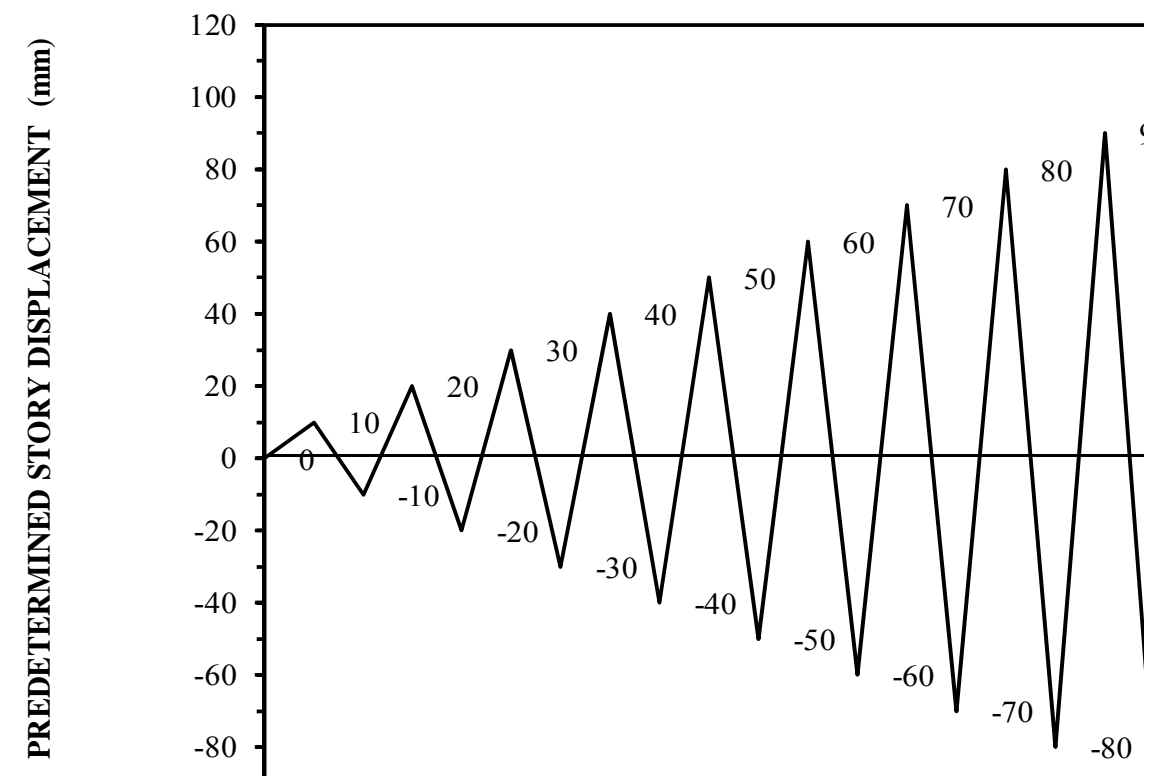

Figure 3. The Loading Program Applied in the Tests 


\section{4. $\quad$ RESULTS}

After the experiment, for each test specimen, the strength envelope, rigidity decline graphics and energy consumption graphics were obtained and these results were compared with each other.

\subsection{The Effect of Infill Wall Length/Infill Wall Height (1/h) to the Behavior of the Frame Systems}

\subsubsection{Frame systems with Infill Wall Length / Infill Wall Height $(\mathrm{l} / \mathrm{h}=1)$}

The experimental test results of the three frame systems with infill wall length/infill wall height $(1 / \mathrm{h}$ $=1$ ) are examined in this section. The aforementioned test specimens are the empty frame system N110, brick wall infilled frame system N111, and brick wall+plaster infilled frame system N112. The strength envelopes of the specimens are given in Figure 4. The maximum horizontal load values are found as $32.37 \mathrm{kN}(\mathrm{N} 110), 41.42 \mathrm{kN}$ (N111), and $56.92 \mathrm{kN}$ (N112) respectively. When the empty frame system was taken as the reference, the increase in the carried horizontal load was $28 \%$ in the brick wall infilled system and $76 \%$ in the brick wall+plaster infilled system. The brick wall + plaster infilled system bears $37 \%$ more horizontal load compared to the brick wall infilled system. It was observed that after the third cycle, the carried horizontal loads decreased in the brick wall and brick wall+plaster infilled systems.

The rigidity decline graphics obtained from the tests of the aforementioned specimens are given in Figure 5. The first cycle rigidities are $1.17 \mathrm{kN} / \mathrm{mm}(\mathrm{N} 110), 2.55 \mathrm{kN} / \mathrm{mm}(\mathrm{N} 111)$, and $3.06 \mathrm{kN} / \mathrm{mm}$ (N112). However, the rigidities decreased in subsequent cycles. The rigidity decrease is more rapid in the brick wall and brick wall+plaster infilled systems than the empty frame systems. Generally during the fifth cycle $(\delta / \mathrm{H}=0.0607)$ the rigidity values in all of the frame systems decrease to approximately $0.5-0.7 \mathrm{kN} / \mathrm{mm}$. Observations made during the experiments revealed that in the fifth cycles a lateral buckling generally begins at the bottom ends of the columns. After this cycle, all systems presented empty frame behavior characteristics. In terms of rigidities obtained from the first cycle, when the reference empty frame was considered as a base, the increase in the first cycle rigidities was $118 \%$ for the brick wall infilled system and $160 \%$ for the brick wall+plaster infilled system.

The cumulative consumed energy graphics determined from the tests are also given in Figure 6. The cumulative consumed energy values after the eighth cycle are $10878 \mathrm{kNmm}, 14877 \mathrm{kNmm}$, and $17978 \mathrm{kNmm}$, respectively. When the reference empty frame was considered as a base, the increase in the cumulative consumed energy was $37 \%$ for the brick wall infilled system and $65 \%$ for the brick wall+plaster infilled system.

\subsubsection{Frame systems with infill wall length/infill wall height $(l / h=2)$}

The test results belonging to the three frame systems with infill wall length/infill wall height $(1 / \mathrm{h}=2)$ are examined in this section. The test specimens were the empty frame system N110, the brick wall infilled frame system N111, and the brick wall+plaster infilled frame system N112. The related specimens' strength envelopes are presented in Figure 7. 


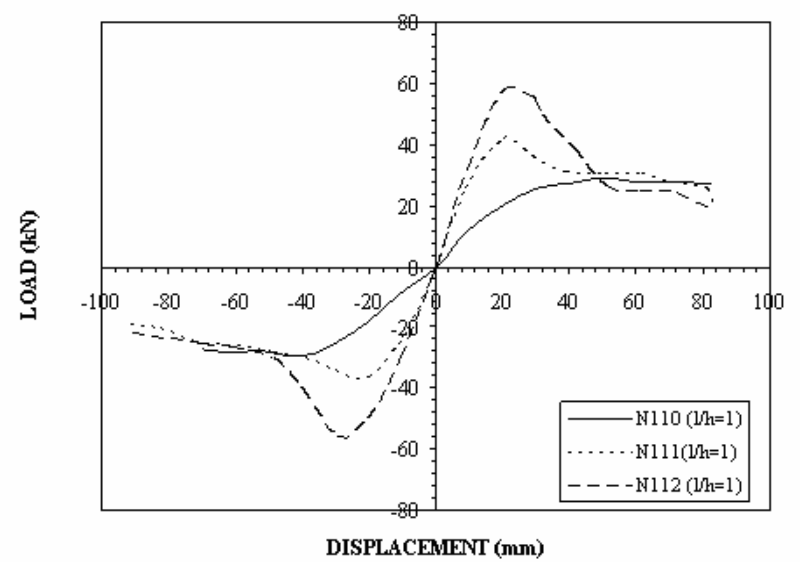

Figure 4. Strength Envelopes of Frame Systems with Infill Wall Length/ Infill Wall Height $(1 / \mathrm{h}=1)$

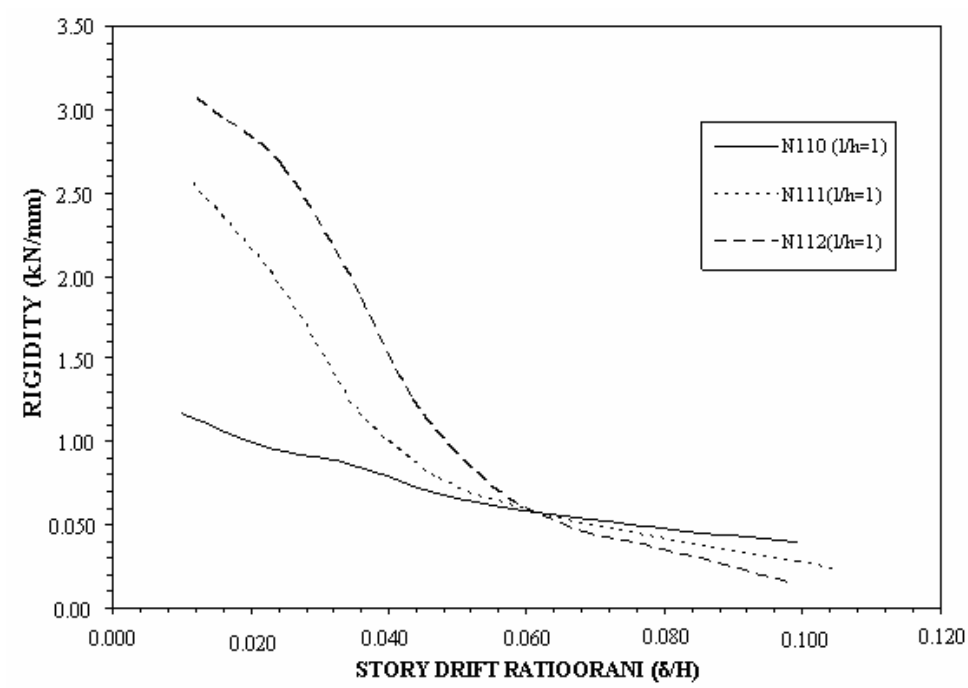

Figure 5. Rigidity Decreasing Graphics of Frame Systems with Infill Wall Length/ Infill Wall Height $(1 / \mathrm{h}=1)$

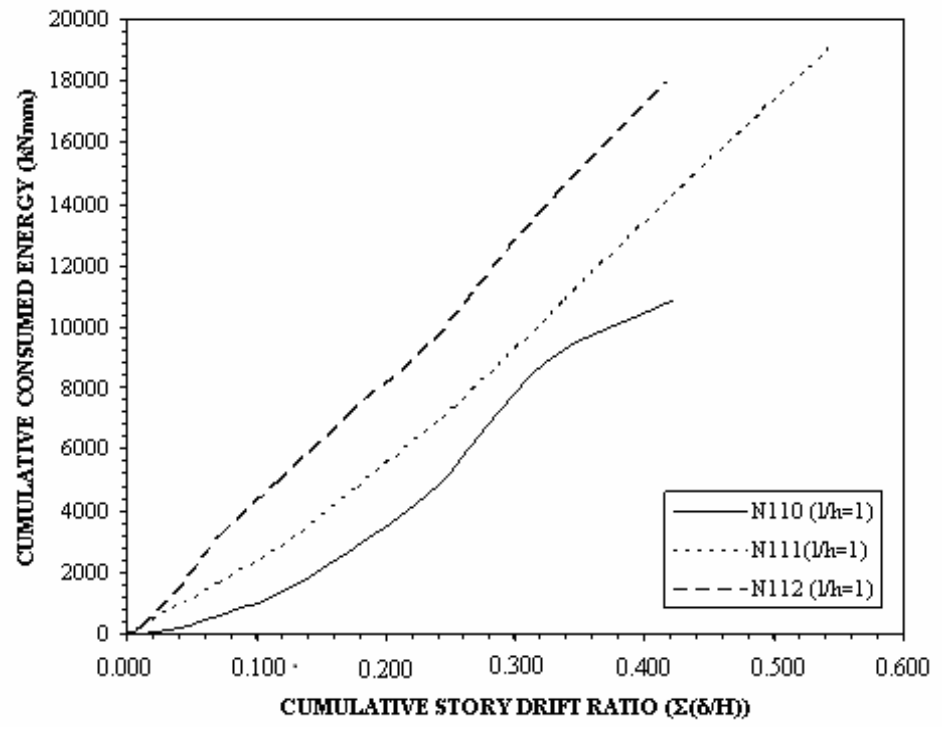

Figure 6. Cumulative Consumed Energy Graphics of Frame Systems with Infill Wall Length/Infill Wall Height $(1 / \mathrm{h}=1)$ 
As seen from Figure 7, the carried maximum horizontal loads were found as $27.15 \mathrm{kN}$ (N110), $45.40 \mathrm{kN}(\mathrm{N} 111)$, and $65.86 \mathrm{kN}(\mathrm{N} 112)$, respectively. When the reference empty frame was considered as a base, the increase in the carried horizontal load was $67 \%$ for the brick wall infilled system and $142 \%$ for the brick wall+plaster infilled system. In the brick wall infilled and brick wall + plaster infilled systems, a general decrease was observed in the carried horizontal load after the second cycle. The rigidity decline graphics obtained from the tests are given in Figure 11.

Looking at Figure 8, while the first cycle rigidity values were $1.21 \mathrm{kN} / \mathrm{mm}(\mathrm{N} 110), 3.83 \mathrm{kN} / \mathrm{mm}$ (N111), and $4.19 \mathrm{kN} / \mathrm{mm}$ (N112), respectively, the rigidities decreased in the subsequent cycles. While the rigidity decrease was more rapid in the brick wall infilled and brick wall +plaster infilled systems, the rigidity decrease in the empty frame system was slower. Generally, the rigidity values in all frame systems in the fifth cycle $(\delta / \mathrm{H}=0.0607)$ decrease to approximately $0.5-0.7 \mathrm{kN} / \mathrm{mm}$. Observations made during the experiments revealed that generally in the fifth cycles $(\delta / H=0.0607)$ a lateral buckling began at the bottom ends of the columns. After this cycle, all systems presented empty frame behavior characteristics. In terms of rigidities obtained from the first cycle, when the reference empty frame was considered as a base, the increase in the first cycle rigidities was $216 \%$ for the brick wall infilled system and $246 \%$ for the brick wall + plaster infilled system.

The cumulative consumed energy graphics are also given in Figure 9. The cumulative consumed energy values after the eighth cycle are $13237 \mathrm{kNmm}, 17406 \mathrm{kNmm}$, and $17886 \mathrm{kNmm}$, respectively. When the reference empty frame was considered as a base, the increase in the cumulative consumed energy became $31 \%$ for the brick wall infilled system and $35 \%$ for the brick wall + plaster infilled system.

\subsubsection{Frame systems with infill wall length/infill wall height $(\mathrm{l} / \mathrm{h}=1 / 2)$}

The test results belonging to three frame systems with infill wall length/infill wall height $(1 / \mathrm{h}=1 / 2)$ are examined in this section. The test specimens are the empty frame system N110, brick wall infilled frame system N111, and the brick wall+plaster infilled frame system N112. The related specimens' strength envelopes are presented in Figure 10. The carried maximum horizontal loads were found to be $12.97 \mathrm{kN}(\mathrm{N} 110), 23.64 \mathrm{kN}$ (N111), and $28.60 \mathrm{kN}(\mathrm{N} 112)$, respectively. When the reference empty frame was considered, the increase in the carried horizontal load was $82 \%$ for the brick wall infilled system and $121 \%$ for the brick wall+plaster infilled system.

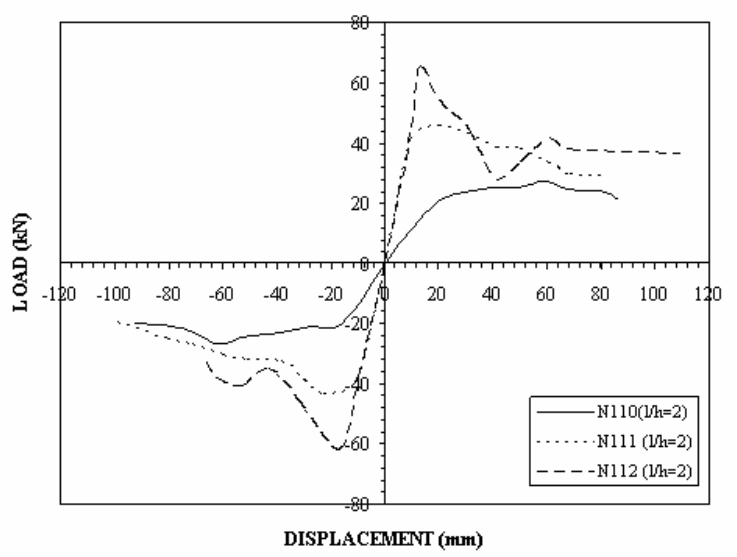

Figure 7. Strength Envelopes of Frame Systems with Infill Wall Length/ Infill Wall Height $(1 / \mathrm{h}=2)$ 


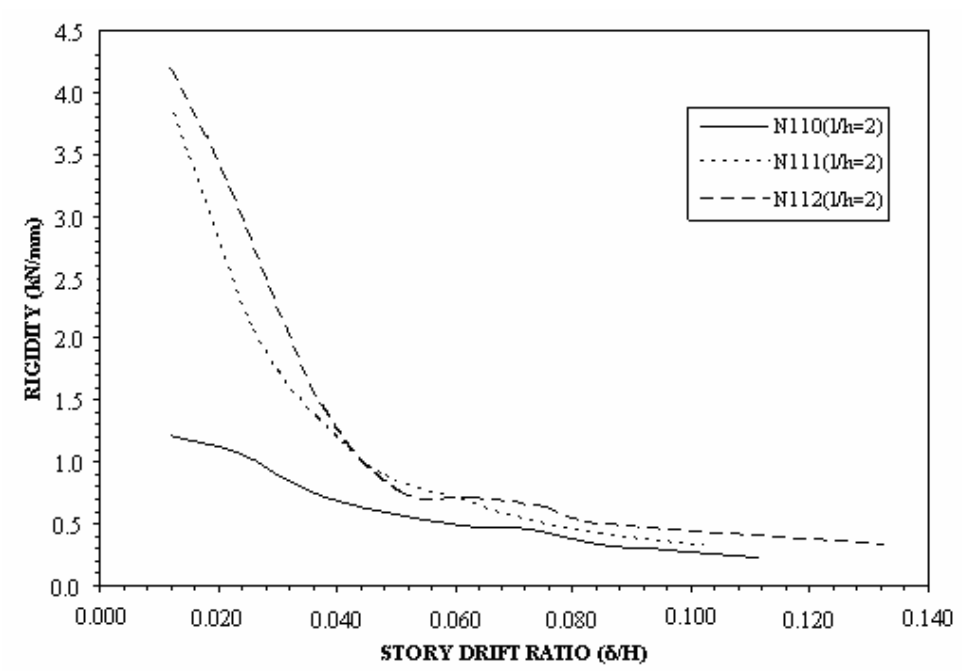

Figure 8. Rigidity Decreasing Graphics of Frame Systems with Infill Wall Length/ Infill Wall Height $(1 / \mathrm{h}=2)$

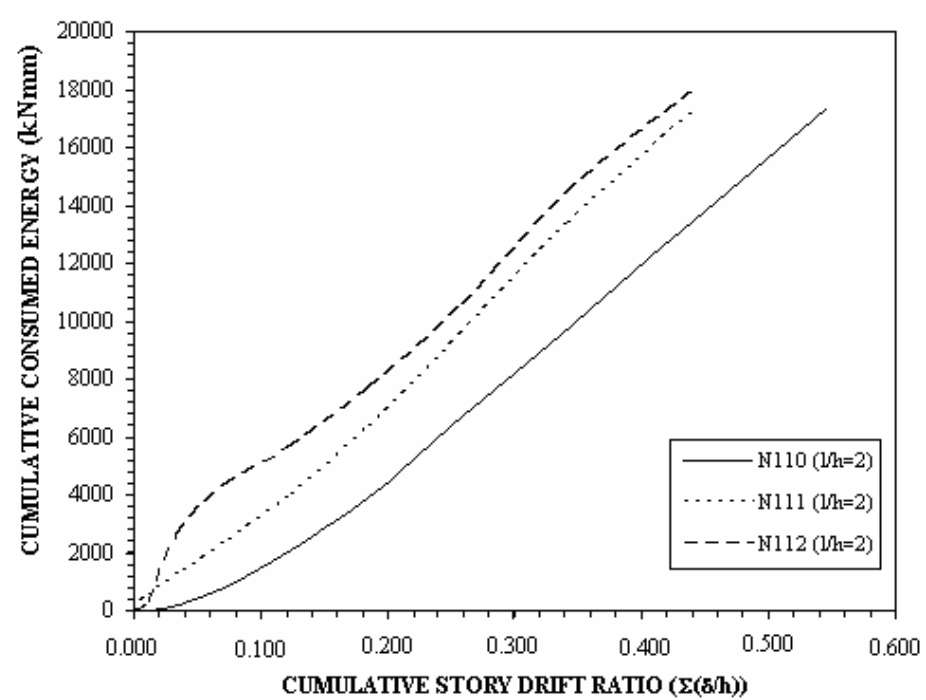

Figure 9. Cumulative Consumed Energy Graphics of Frame Systems with Infill Wall Length/Infill Wall Height $(1 / \mathrm{h}=2)$

The rigidity decrease graphics obtained from the specimen tests are given in Figure 11. While the first cycle rigidity values were $0.38 \mathrm{kN} / \mathrm{mm} /(\mathrm{N} 110), 1.05 \mathrm{kN} / \mathrm{mm}(\mathrm{N} 111)$, and $1.18 \mathrm{kN} / \mathrm{mm}(\mathrm{N} 112)$, respectively, the rigidities decreased in the subsequent cycles. While the rigidity decrease was more rapid in the brick wall infilled and brick wall+plaster infilled systems, the rigidity decrease in empty frame system was slower. After the sixth cycle $(\delta / \mathrm{H}=0.0374)$ the decrease in rigidity values of all frame systems was slowed and the rigidity values decreased approximately to $0.15-0.40$ $\mathrm{kN} / \mathrm{mm}$. In terms of rigidities obtained from the first cycle, when the reference empty frame was considered as a base, the increase in the first cycle rigidities was $176 \%$ for the brick wall infilled system and $210 \%$ for the brick wall+plaster infilled system.

The cumulative consumed energy graphics determined from the tests are also given in Figure 12. The cumulative consumed energy values after the ninth cycle are $2991 \mathrm{kNmm}(\mathrm{N} 110), 5871 \mathrm{kNmm}$ (N111), and $7429 \mathrm{kNmm}$ (N112), respectively. When the reference empty frame was considered as a base, the increase in the cumulative consumed energy was $96 \%$ for the brick wall infilled system and $148 \%$ for the brick wall + plaster infilled system. 


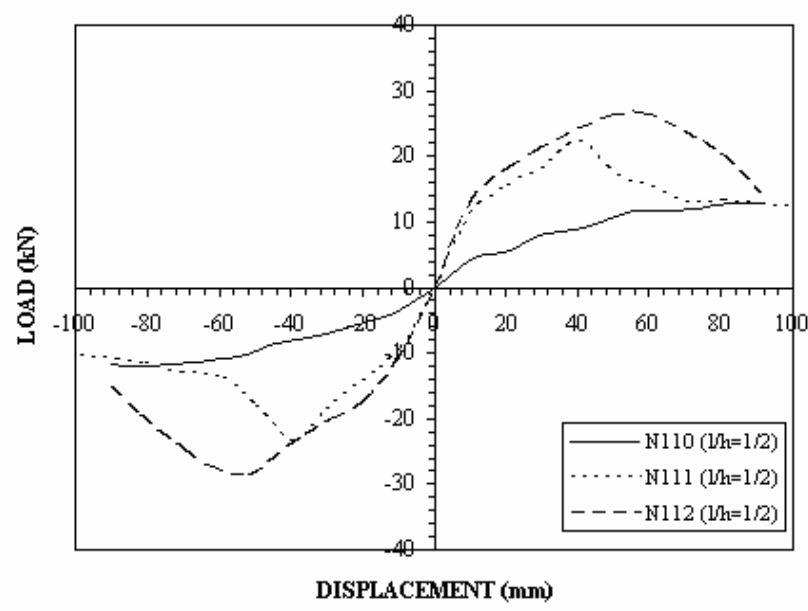

Figure 10. Strength Envelopes of Frame Systems with Infill Wall Length/ Infill Wall Height $(1 / \mathrm{h}=1 / 2)$

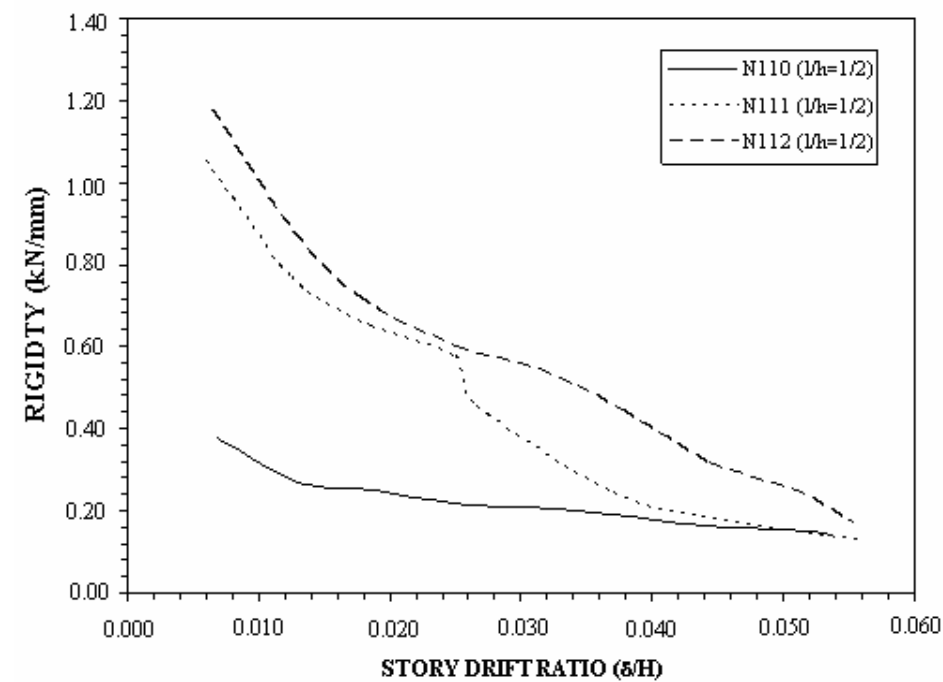

Figure 11. Rigidity Decreasing Graphics of Frame Systems with Infill Wall Length/ Infill Wall Height $(1 / \mathrm{h}=1 / 2)$

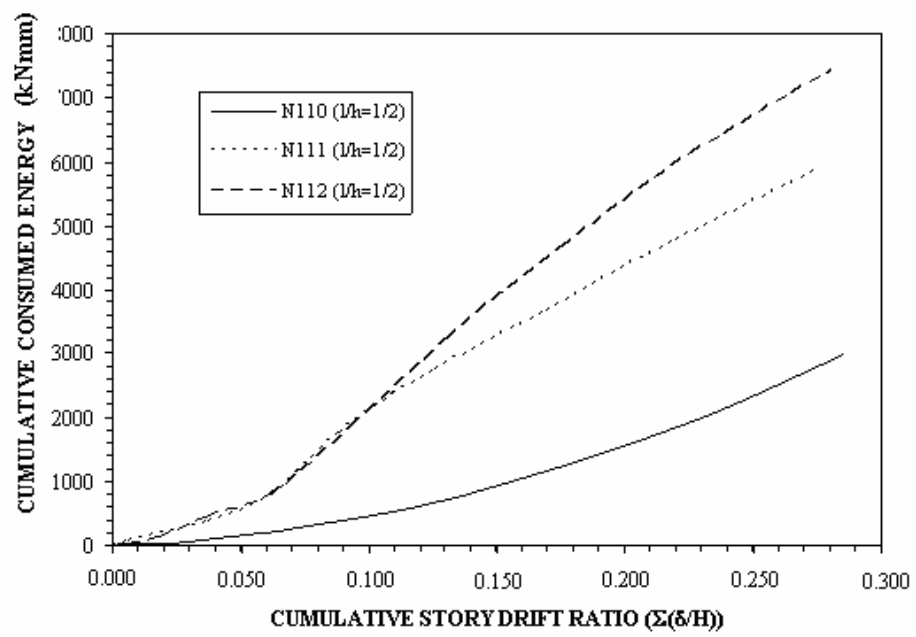

Figure 12. Cumulative Consumed Energy Graphics of Frame Systems with Infill Wall Length/Infill Wall Height $(1 / \mathrm{h}=1 / 2)$ 


\subsection{The Effect of Infill Wall Characteristic on the Behavior of the Frame Systems}

\subsubsection{Empty frame systems}

The results belonging to three tested empty frames with various dimensions are examined in this section. The related test specimens are N110 $(1 / \mathrm{h}=1), \mathrm{N} 110(1 / \mathrm{h}=2), \mathrm{N} 110(1 / \mathrm{h}=1 / 2)$ frame systems of single story-single span and length/height ratios are respectively 1,2 , and $1 / 2$. These specimens' strength envelopes are given in Figure 13.

As seen from Figure 13, the carried maximum horizontal load values were $32.37 \mathrm{kN}, 27.15 \mathrm{kN}$, and $12.97 \mathrm{kN}$, respectively. The $1 / \mathrm{h}=2$ frame system carries a $84 \%$ ratio and the $1 / \mathrm{h}=1 / 2$ frame system carries a $40 \%$ ratio of the reference $1 / \mathrm{h}=1$ frame system's horizontal load.

The rigidity decline graphics determined from the aforementioned specimen tests are given in Figure 14. While the first cycle rigidity values were $1.17 \mathrm{kN} / \mathrm{mm}, 1.21 \mathrm{kN} / \mathrm{mm}$, and $0.38 \mathrm{kN} / \mathrm{mm}$, respectively, the rigidities decreased in the subsequent cycles. Considering the first cycle rigidities determined from the first cycle, the $1 / \mathrm{h}=2$ frame system had a $103 \%$ ratio and the $1 / \mathrm{h}=1 / 2$ frame system has a $61 \%$ ratio of the $1 / \mathrm{h}=1$ frame system's starting rigidity value.

The first cycle rigidities decreased rapidly in the progressive cycles, in which the $1 / \mathrm{h}=1$ and $1 / \mathrm{h}=2$ frame systems had a value of $0.40 \mathrm{kN} / \mathrm{mm}$ in the eighth cycle, and the $1 / \mathrm{h}=1 / 2$ frame system had a value of $0.15 \mathrm{kN} / \mathrm{mm}$ in the ninth cycle.

The cumulative consumed energy graphics obtained from the tests of the mentioned specimens are also given in Figure 15. It indicates that the cumulative consumed energy values are $10878 \mathrm{kNmm}$ and $13237 \mathrm{kNmm}$ for the $(1 / \mathrm{h}=1)$ and $(1 / \mathrm{h}=2)$ frame systems, respectively, at the end of the eighth cycle and $2991 \mathrm{kNmm}$ for the $(\mathrm{l} / \mathrm{h}=1 / 2)$ frame system at the end of the ninth cycle.

In terms of consumed energy, the $1 / \mathrm{h}=2$ frame system consumed $22 \%$ more energy than $\mathrm{he} 1 / \mathrm{h}=1$ frame system. Again (at the level of $\delta / H=0.0277$ ), the $1 / \mathrm{h}=1 / 2$ frame system consumed $63 \%$ of the energy of the $1 / \mathrm{h}=1$ frame system

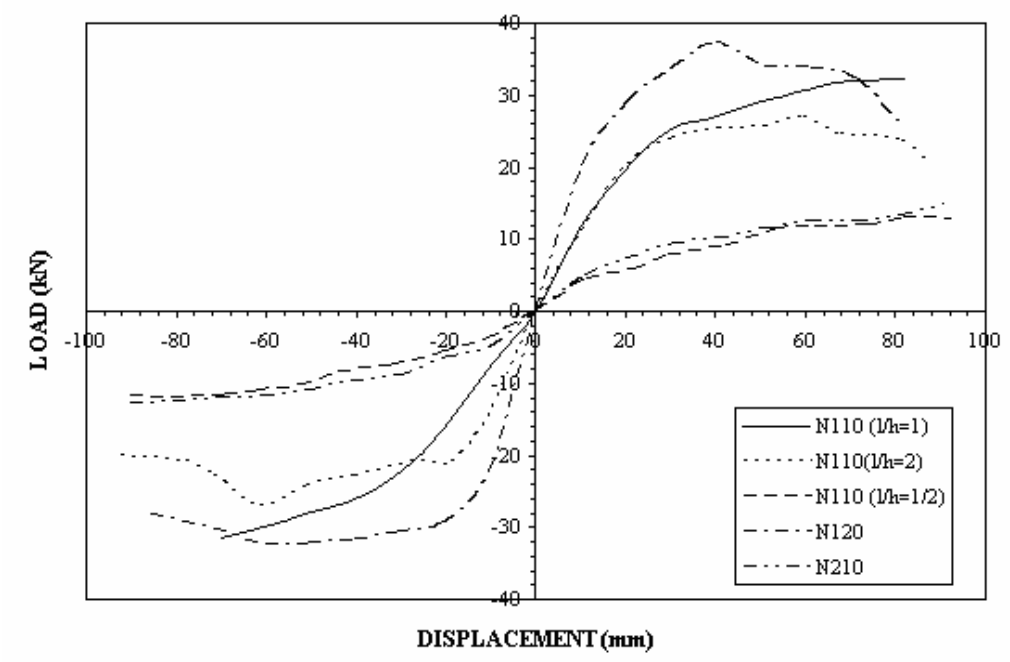

Figure 13. Strength Envelopes of Frame Systems with No Infill Wall 


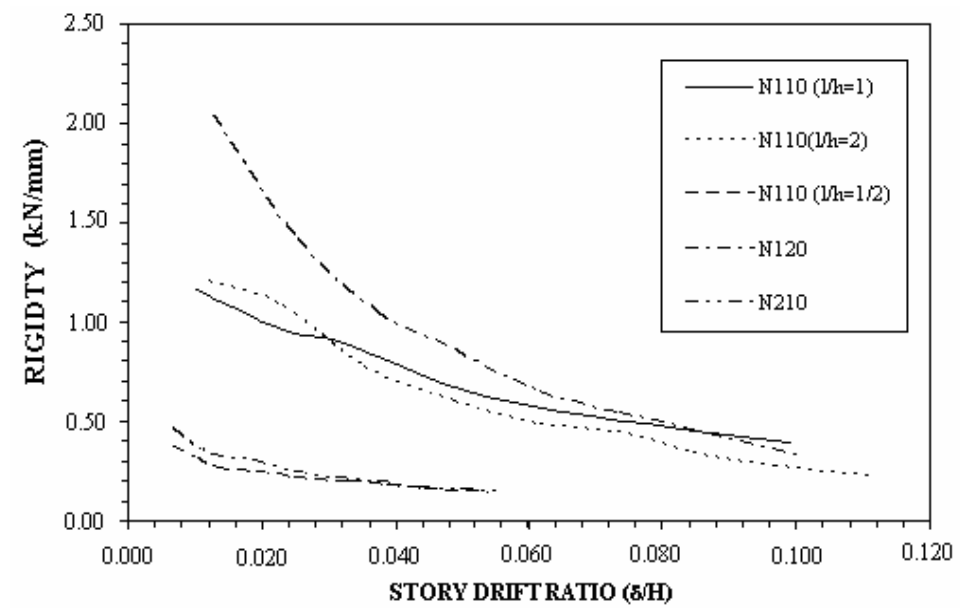

Figure 14. Rigidity Decreasing Graphics of Frame Systems with No Infill Wall

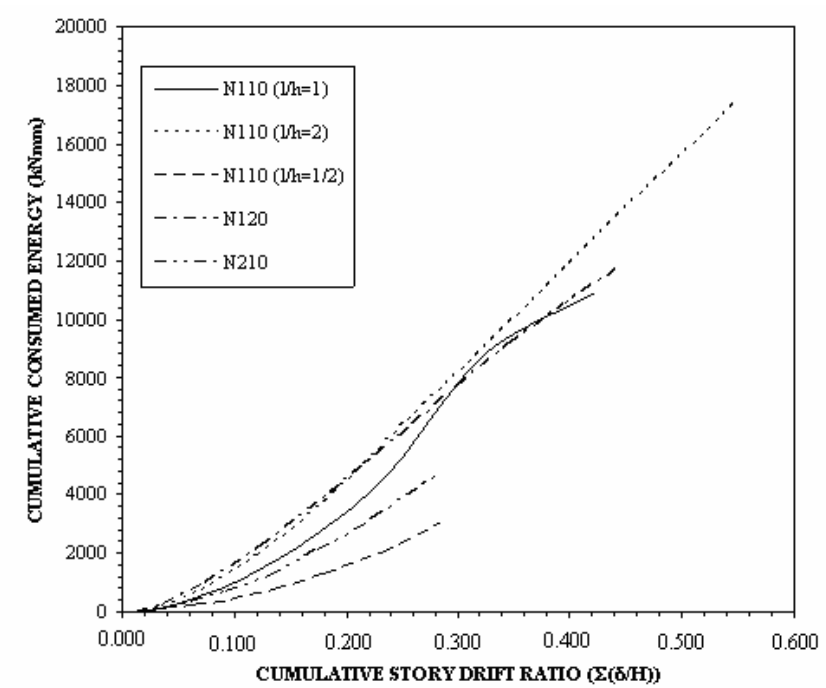

Figure 15. Cumulative Consumed Energy Graphics of Frame Systems with No Infill Wall

\subsubsection{Brick wall infilled frame systems}

The results of three tested brick wall infilled frame systems with various dimensions are investigated in this study. These test specimens were brick wall infilled frame systems with dimensions of $(1 / \mathrm{h}=1),(1 / \mathrm{h}=2)$ and $(1 / \mathrm{h}=1 / 2)$. Their strength envelopes are given in Figure 16 .

As seen from Figure 16, the carried maximum horizontal loads were found as $41.42 \mathrm{kN}, 45.40 \mathrm{kN}$, and $23.64 \mathrm{kN}$, respectively. When the reference empty frame was considered as a base, the increase in the carried horizontal load was $82 \%$ for the brick wall infilled system and $121 \%$ for the brick wall + plaster infilled system. The $1 / \mathrm{h}=2$ frame system carries $110 \%$ and the $1 / \mathrm{h}=1 / 2$ frame system carries $57 \%$ of the horizontal load of the reference $1 / \mathrm{h}=1$ frame system.

The rigidity decline graphics obtained from the aforementioned specimen tests are given in Figure 17. While the first cycle rigidity values were $2.55 \mathrm{kN} / \mathrm{mm}, 3.83 \mathrm{kN} / \mathrm{mm}$, and $1.05 \mathrm{kN} / \mathrm{mm}$ (N112), respectively, the rigidities decreased in the subsequent cycles. While the rigidity decrease was more rapid in the $(1 / \mathrm{h}=1)$ and $(1 / \mathrm{h}=2)$ specimens, it was slower in other specimens. Considering the first cycle rigidities determined from the first cycle, the $1 / \mathrm{h}=2$ frame system has $150 \%$ and the $1 / \mathrm{h}=1 / 2$ frame system has $41 \%$ of the starting rigidity value of the $1 / \mathrm{h}=1$ reference frame system. First cycle rigidities rapidly decreased in progressive cycles in which the $0.30 \mathrm{kN} / \mathrm{mm}$ value was reached in the single story-single span $1 / \mathrm{h}=1$ and $1 / \mathrm{h}=2$ frame systems in the eighth cycle, and $0.15 \mathrm{kN} / \mathrm{mm}$ in the $1 / h=1 / 2$ frame system in the ninth cycle. 
The cumulative consumed energy graphics obtained from these specimens' tests are also presented in Figure 18. It indicates that the cumulative consumed energy values after the eighth cycle were $14877 \mathrm{kNmm}$ and $17406 \mathrm{kNmm}$, respectively for the $(1 / \mathrm{h}=1)$ and $(1 / \mathrm{h}=2)$ frame systems, and 5871 $\mathrm{kNmm}$ after the ninth cycle for the $(1 / \mathrm{h}=1 / 2)$ frame system.

In terms of consumed energy, the $1 / \mathrm{h}=2$ frame system consumed $17 \%$ more energy than $\mathrm{the} 1 / \mathrm{h}=1$ frame system. Again (at level of $\delta / H=0.0277$ ), the $1 / \mathrm{h}=1 / 2$ frame system consumed $70 \%$ of the energy of the $1 / \mathrm{h}=1$ frame system.

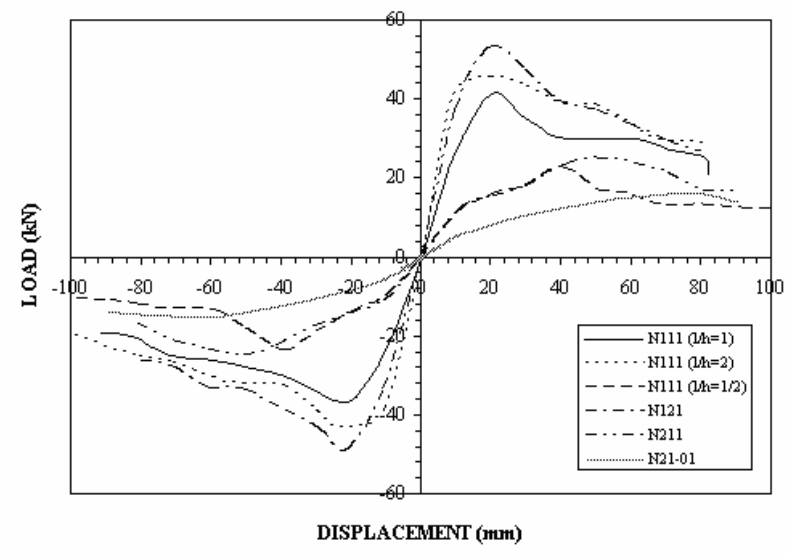

Figure 16. Strength Envelopes of Frame Systems with Infill Brick Wall

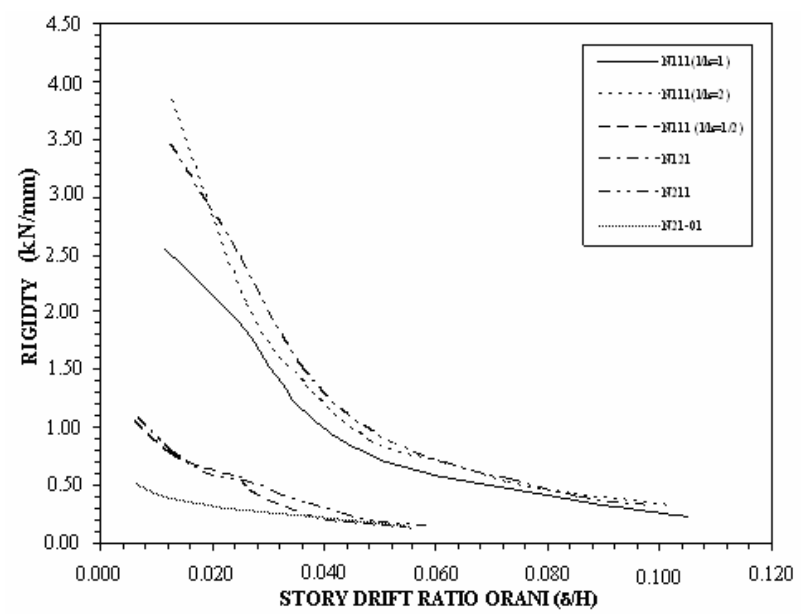

Figure 17. Rigidity Decreasing Graphics of Frame Systems with Infill Brick Wall

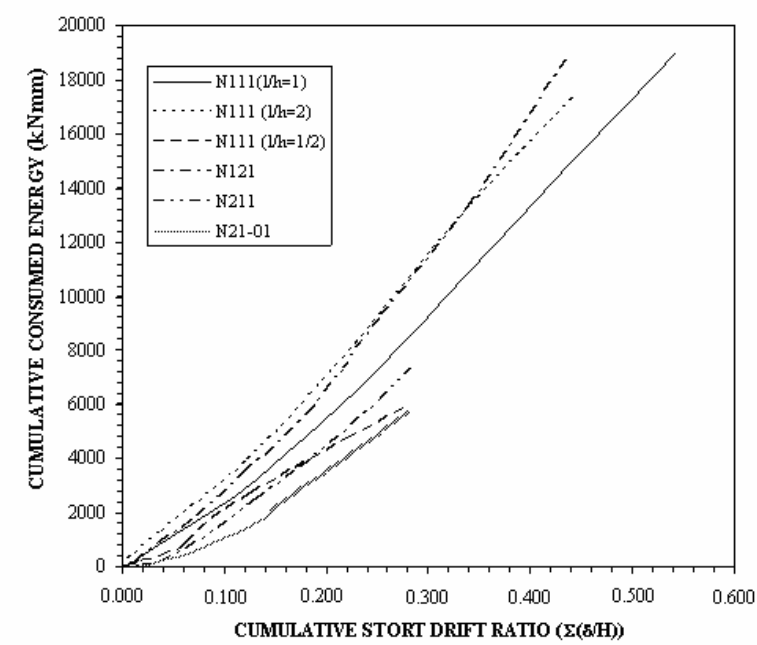

Figure 18. Cumulative Consumed Energy Graphics of Frame Systems with Infill Brick Wall 


\subsubsection{Brick wall+plaster infilled frame systems}

The results of three brick wall+plaster infilled frame systems tested in this study and with various dimensions are investigated in this section. The test specimens are the brick wall+plaster infilled frame systems with dimensions of $(1 / \mathrm{h}=1),(1 / \mathrm{h}=2)$, and $(1 / \mathrm{h}=1 / 2)$. The strength envelopes of these specimens are given in Figure 19. The carried maximum horizontal loads were found as $56.92 \mathrm{kN}$, $65.86 \mathrm{kN}$, and $28.60 \mathrm{kN}$, respectively. The $1 / \mathrm{h}=2$ frame system carried $116 \%$, and the $1 / \mathrm{h}=1 / 2$ frame system carried $50 \%$ of the horizontal load of the $1 / \mathrm{h}=1$ reference frame system.

The rigidity decline graphics obtained from the specimen tests are given in Figure 20. While the first cycle rigidity values were $3.06 \mathrm{kN} / \mathrm{mm}, 4.19 \mathrm{kN} / \mathrm{mm}$, and $1.18 \mathrm{kN} / \mathrm{mm}$, respectively, the rigidities decreased in the subsequent cycles. Considering the first cycle rigidities determined from the first cycle, the $1 / \mathrm{h}=2$ frame system has $136 \%$, and the $1 / \mathrm{h}=1 / 2$ frame system has $39 \%$ of the starting rigidity value of the $1 / \mathrm{h}=1$ reference frame system. First cycle rigidities rapidly decreased in progressive cycles in which the $0.15-0.45 \mathrm{kN} / \mathrm{mm}$ interval was obtained for the $1 / \mathrm{h}=1$ and $1 / \mathrm{h}=2$ frame systems in the eighth cycle and a value of $0.18 \mathrm{kN} / \mathrm{mm}$ was obtained for the $1 / \mathrm{h}=1 / 2$ frame system in the ninth cycle.

The cumulative consumed energy graphics obtained from these specimens' tests are given in Figure 21. Examining Figure 24, the cumulative consumed energy values after the eighth cycle are 17978 $\mathrm{kNmm}$ and $17886 \mathrm{kNmm}$, respectively, for the $(1 / \mathrm{h}=1)$ and $(1 / \mathrm{h}=2)$ frame systems, and $7429 \mathrm{kNmm}$ after the ninth cycle for the $(1 / \mathrm{h}=1 / 2)$ frame system.

In terms of consumed energy, the $1 / \mathrm{h}=2$ frame system consumed $14 \%$ less energy than $1 / \mathrm{h}=1$ frame system. Again (at level of $\delta / H=0.0277$ ), the $1 / \mathrm{h}=1 / 2$ frame system consumed $70 \%$ of the energy of the $1 / \mathrm{h}=1$ frame system. The obtained test results are given in Table 2 .

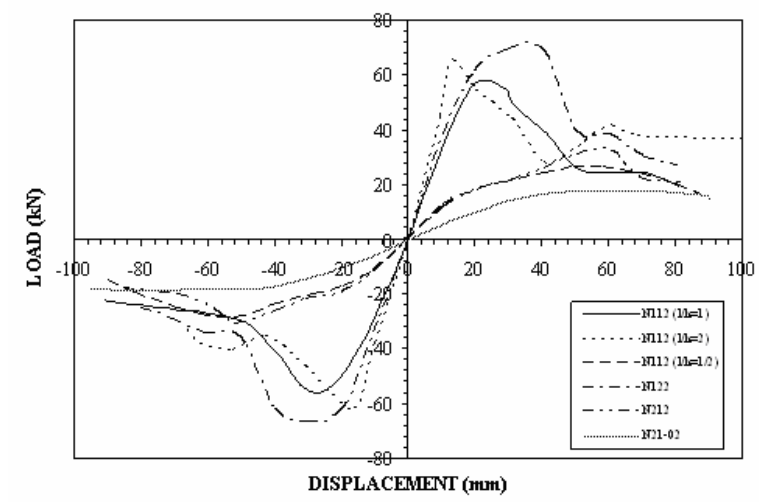

Figure 19. Strength Envelopes of Frame Systems with Brick Wall+Plaster Infilled Wall

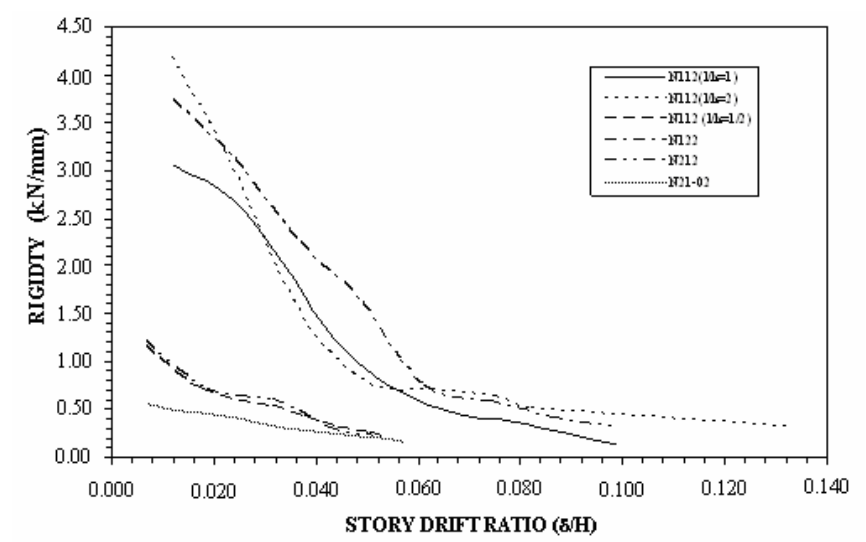

Figure 20. Rigidity Decreasing Graphics of Frame Systems with Brick Wall+ Plaster Infilled Wall 


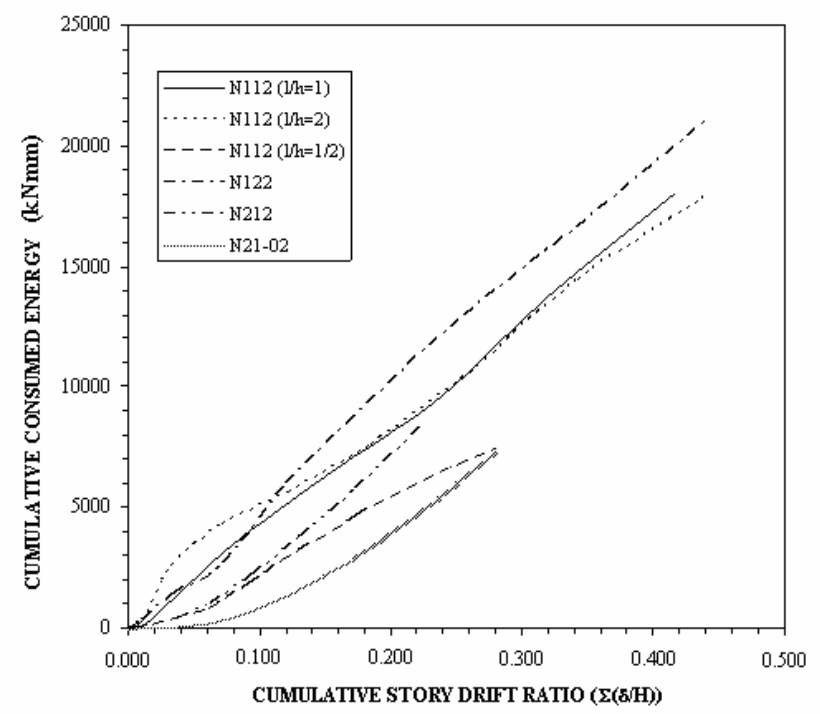

Figure 21. Cumulative Consumed Energy Graphics of Frame Systems with Brick Wall+Plaster Infilled Wall

Table 8. Tabulation of Experimental Results

\begin{tabular}{|c|c|c|c|c|c|c|c|c|}
\hline \multirow[b]{2}{*}{ Specimens } & \multicolumn{2}{|c|}{$\begin{array}{l}\text { Experimental } \\
\text { Maximum } \\
\text { Lateral Load }\end{array}$} & \multirow[b]{2}{*}{$\begin{array}{c}\text { Initial } \\
\text { Rigidity } \\
(\mathrm{kN} / \mathrm{mm})\end{array}$} & \multicolumn{2}{|c|}{ Ultimate Rigidity } & \multicolumn{2}{|c|}{$\begin{array}{l}\text { Energy Consumed } \\
\text { at the End of the Test }\end{array}$} & \multirow[b]{2}{*}{$\begin{array}{l}\text { Failure } \\
\text { Type }^{*}\end{array}$} \\
\hline & $\begin{array}{l}\text { Load } \\
(\mathrm{kN})\end{array}$ & $(\delta / H)$ & & $\begin{array}{l}\text { Rigidit } \\
\mathrm{y} \\
(\mathrm{kN} / \mathrm{m} \\
\mathrm{m})\end{array}$ & $(\delta / H)$ & $\begin{array}{l}\text { Cumulativ } \\
\text { e } \\
\text { Consumed } \\
\text { Energy } \\
(\mathrm{kNmm})\end{array}$ & $\begin{array}{l}\text { Cumul. } \\
\Sigma(\delta / \mathrm{H})\end{array}$ & \\
\hline$(1)$ & $(2)$ & $(3)$ & $(4)$ & $(5)$ & (6) & $(7)$ & $(8)$ & (9) \\
\hline N110 & 32.37 & 0.099 & 1.46 & 0.40 & 0.0994 & 10878 & 0.422 & SFF \\
\hline N111 & 41.42 & 0.024 & 10.75 & 0.23 & 0.1108 & 14877 & 0.437 & OTC \\
\hline N112 & 56.92 & 0.0247 & 19.30 & 0.15 & 0.0986 & 17978 & 0.416 & OTC \\
\hline N110 & 27.15 & 0.072 & 1.28 & 0.23 & 0.1115 & 13237 & 0.435 & SFF \\
\hline $\begin{array}{c}\mathrm{N} 111 \\
(1 / \mathrm{h}=2)\end{array}$ & 45.50 & 0.0241 & 13.20 & 0.33 & 0.1019 & 17406 & 0.437 & OTC-CC \\
\hline $\begin{array}{c}\mathrm{N} 112 \\
(\mathrm{l} / \mathrm{h}=2)\end{array}$ & 63.23 & 0.0243 & 25.80 & 0.33 & 0.1323 & 17886 & 0.439 & $\mathrm{CC}$ \\
\hline N110 & 12.97 & 0.051 & 0.46 & 0.14 & 0.0538 & 2991 & 0.285 & $\begin{array}{l}-- \\
\end{array}$ \\
\hline $\begin{array}{c}\mathrm{N} 111 \\
(\mathrm{l} / \mathrm{h}=1 / 2)\end{array}$ & 23.64 & 0.0244 & 3.72 & 0.13 & 0.0560 & 5871 & 0.275 & OTC-CC \\
\hline $\begin{array}{c}\mathrm{N} 112 \\
(\mathrm{l} / \mathrm{h}=1 / 2)\end{array}$ & 28.60 & 0.0322 & 6.10 & 0.17 & 0.0552 & 7429 & 0.281 & OTC-CC \\
\hline
\end{tabular}

*(CC) denotes failure with compression crush, (OTC) failure with oblique tensional crack and (SFF) steel frame failure. 


\section{DISCUSSION OF RESULTS AND CONCLUSION}

The results obtained by the experimental study are given in the following;

1. The lateral stiffness, lateral load-bearing, and energy consumption capacities of the steel frame under lateral loading considerably increased with the aid of the infill walls of various structural characteristics.

- Depending on the $\mathrm{L} / \mathrm{h}$ ratio, the unplastered and plastered infill walls increased the lateral load-bearing capacity of empty steel frames by $28 \%-82 \%$ and $76 \%-142 \%$ proportions, respectively.

- Depending on the $\mathrm{L} / \mathrm{h}$ ratio, the unplastered and plastered infill walls increase the initial stiffness values of empty steel frames by $118 \%-216 \%$ and $160 \%-246 \%$ proportions, respectively.

- Similarly, again depending on the $\mathrm{L} / \mathrm{h}$ ratio, the unplastered and plastered infill walls increase the cumulative consumed energy values of empty steel frames by $31 \%-96 \%$ and $35 \%-148 \%$ proportions, respectively.

2. The horizontal stiffness, lateral load-bearing, and energy consumption capacities of the frame systems are considerably affected due to the varying infill wall length/height $(1 / \mathrm{h}) \mathrm{ratio}$.

3. The lateral load-bearing capacity increases when the infill wall length/height $(1 / \mathrm{h})$ ratio is greater than 1 and considerably decreases when $(1 / h)<1$.

4. As seen from the tests, the plaster application on brick walls considerably increases the lateral stiffness, energy consumption, and horizontal failure load characteristics of the infilled frame systems. Therefore, the plastering process should be absolutely required for practical applications.

\section{REFERENCES}

[1] Dawe, J.L. and Seah, C.K., "Behaviour of Masonry Infilled Steel Frames", Can. J. Civ. Eng. 1989, Vol. 16, No. 6, pp. 856-876.

[2] Dukuze, et al., "Assessment of Diagonal and Racking Loading of RC Infilled Frames", Proceedings of the $8^{\text {th }}$ Canadian Masonry Symposium, Jasper, Alberta 1998, June, pp. 385-397.

[3] Flangan, R.D., et al., "Experimental Testing of Hollow Clay Tile Infilled Frames", Proc. $6^{\text {th }}$ Can. Masonry Symp., Univ of Saskatchewan, Canada, 1992, pp. 633-644.

[4] Hakam, Z.H.R., "Retrofit of Hollow Concrete Masonry Infilled Steel Frames using Glass Fiber Reinforced Plastic Laminates", Ph.D. Thesis, Drexel University, 2000.

[5] Holmes, M., "Steel Frames with Brickwork and Concrete Infilling", Proc. Inst. Civ. Engrs., 1961, Vol. 19, No. 6501, pp. 473-478.

[6] Kaltakc1, M.Y. and Koken, A., "An Experimental and Theoretical Study On The Behavior Of Infilled Steel Frames Under Reversed-Cycling Loading”, Research Project, Selcuk University, BAP, Konya, Turkey, 2003.

[7] Kaltakc1, M.Y. and Koken, A., "Cyclic Behaviour of Infilled Steel Frames", Tubitak Project Number: Intag569, Ankara, Turkey, 2003.

[8] Köken, A., "Cyclic Behaviour of Infilled Steel Frames With Multi Storey and Multibay a Theoretical and Experimental Investigation", PhD Thesis, Selcuk University, Natural and Applied Sci. Inst., Konya, Turkey, 2003. 
[9] Mehrabi, A.B., et al., "Experimental Evaluation of Masonry Infilled RC Frames", Journal of Structural Engineering, ASCE, 1996; Vol. 122, No.3, March pp. 228-237.

[10] Mainstone, R.J. and Weeks, G.A., "The Influence of Bounding Frame on the Racking Stiffness and Strength of Brickwalls", Proc. $2^{\text {nd }}$ Int Brick Masonry Conf., Stoke on Trent England, 1970, pp. 165-171.

[11] Mander, A.B., et al., "An Experimental Study on the Seismic Performance of Brick Infilled Steel Frames with and Without Retrofit", Rep. NCEER-93-0001, State Univ. of New York at Buffalo. N.Y., 1993.

[12] Moghaddam, et al., "The State of Art in Infilled Frames", ESEE Research Report No. 87-2, Civil Engineering Department, Imperial Collage of Science and Technology; August 1987.

[13] Stafford, S., "Lateral Stiffness of Infilled Frames", J. Struc. Div. ASCE, 1962, Vol. 88, No. 6, pp. 183-199.

[14] Stafford, S., "Behaviour of the Square Infilled Frames", J. Struc. Div. ASCE, 1966, Vol. 92 , No. 1, pp. 381-403. 